\title{
Hubungan Karakter Disiplin Siswa dengan Hasil Belajar Sosiologi Siswa Kelas XI IPS di SMA Negeri 4 Padang
}

\author{
Mia Fahira Martias ${ }^{1}$, Desri Nora ${ }^{2}$ \\ ${ }^{1,2}$ Universitas Negeri Padang \\ Email : miafahira19@yahoo.com, desrinora@fis.unp.ac.id
}

\begin{abstract}
Abstrak
Penelitian ini memiliki tujuan untuk mengetahui hubungan antara karakter disiplin dengan hasil belajar sosiologi siswa di SMA Negeri 4 Padang. Jenis penelitian ini tergolong penelitian ex post facto. Subjek dalam penelitian ini adalah siswa SMA Negeri 4 Padang, teknik pengambilan sampel adalah proportional random sampling, dengan jumlah sampel 78 siswa. Variabel yang diteliti yaitu: (1) variabel bebas: karakter disiplin (X), 2) variabel terikat: hasil belajar siswa (Y). Pengumpulan data pada penelitian ini menggunakan metode angket dengan skala likert. Keabsahan data menggunakan uji validitas dan reliabilitas. Teknik analisis data untuk uji hipotesis menggunakan rumus korelasi product moment. Hasil uji hipotesis dengan rumus korelasi product moment diperoleh nilai $\mathrm{r}_{\text {hitung }} 1,402>\mathrm{r}_{\text {tabel }} 0.222$, hal ini berarti terdapat hubungan antara karakter disiplin dengan hasil belajar siswa. Pada penelitian ini terdapat 5 indikator. Pertama, indikator ketaatan terhadap tata tertib di sekolah memiliki $\mathrm{r}_{\text {hitung }} 1,007$ dengan $\mathrm{r}_{\text {tabel }}$ 0,222 . Kedua, indikator ketaatan terhadap kegiatan belajar di sekolah, pada indikator ini nilai $\mathrm{r}_{\text {hitung }} 1.185$ dan nilai $\mathrm{r}_{\text {tabel }}$ 0,222. Ketiga, indikator ketaatan dalam mengerjakan tugas-tugas pelajaran, memiliki nilai $\mathrm{r}_{\text {tabel }} 1,089$ dan $\mathrm{r}_{\text {hitung }} 0,222$. Keempat, indikator mengucapkan salam. Memiliki nilai $\mathrm{r}_{\text {hitung }} 0,872$ dan $\mathrm{r}_{\text {tabel }}$ 0,222 . Kelima, indikator berdoa ketika berktivitas. Nilai $r_{\text {hitung }} 1,405$ dengan $r_{\text {tabel }} 0,222$. Hasil penelitian sesuai dengan pendapat teori karakter dari Lickona yang menyatakan bahwa karakter berkaitan dengan konsep moral, sikap moral dan perilaku moral, karakter yang dibelajarkan dengan baik pada proses pembelajaran akan memperlihatkan munculnya pengetahuan tentang kebaikan, keinginan untuk berbuat baik dan melakukan perbuatan baik, sehingga hasil belajar sebagai output dari proses pembelajaran akan berhasil baik.
\end{abstract}

Kata kunci: Hasil Belajar, Karakter Disiplin, Siswa

\begin{abstract}
This study have a purpose to find out the relationship between the character of discipline with sociology learning outcomes of students in SMA Negeri 4 Padang. This type of research is classified as ex post facto research. The subjects in this study were high school students of Padang 4 Padang. The research sample was taken by stratified random sampling with a total sample of 78 students. This study uses two variables, namely: (1) independent variable: discipline character $(X)$, 2) dependent variable: student learning outcomes $(Y)$. Data collection in this study used a questionnaire with a linkert scale. Data validity uses validity and reliability tests. The data analysis technique used is descriptive analysis to calculate the mean, median, mode, and standard deviation values. Data analysis for hypothesis testing uses the product moment correlation formula and to find out the percentage of the degree of influence of the variable $X$ on the variable $Y$ used the coefficient of determination. Hypothesis test results with the product moment correlation formula obtained rcount value of $1.402>$ rtable 0.222 , this means there is a relationship between the character of discipline with student learning outcomes. In this study there are 5 indicators. First, the indicator of adherence to school rules has a count of 1.007 with a rtable of 0.222 . Second, indicators of adherence to learning activities in schools, in this indicator the value of $r$ count 1.185 and rtable value of 0.222 . Third, the indicator of obedience in doing the lesson assignments, has a rtabel value of 1.089 and rcount of 0.222 . Fourth, indicators say hello. Have a count value of 0.872 and rtable of 0.222 . Fifth, indicators pray when active. The value of $r$ count 1.405 with $r$ table 0.222 . Of the five indicators clearly seen that the calculated $r$ value is greater than the rtable value, meaning that the five indicators have a correlation with learning outcomes or in other words have a relationship with learning outcomes.
\end{abstract}

Keywords: Character of Responsibility, Discipline Character, Students

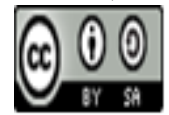

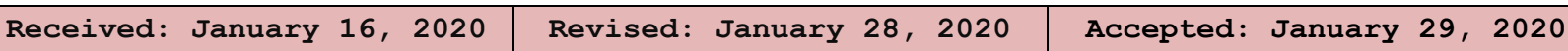

Jurnal Sikola: Jurnal Kajian Pendidikan dan Pembelajaran Vol. 1, No. 3, Th. 2020 


\section{Pendahuluan}

Pemerintah Indonesia bersungguh-sungguh untuk mencerdaskan kehidupan bangsa, dengan mengembangkan kemampuan dan membentuk karakter sehingga tercipta peradaban bangsa yang bermartabat. (Rosniati Haim, 2014). Oleh karena itu karakter menjadi isu utama dalam dunia pendidikan, selain menjadi bagian dari proses pembentukan akhlak anak bangsa, karakter pun diharapkan dapat menjadi pondasi utama dalam mensukseskan Indonesia Emas 2025 (Baroroh, 2012). Perkembangan ilmu pengetahuan, teknologi dan seni yang berkembang dengan pesatnya dapat memicu sebuah perubahan, termasuk perubahan perilaku, karakter dan gaya hidup (Atika, 2014). Karakter bangsa yang tertanam secara sistematis dapat dilakukan secara baik salah satunya adalah melalui penambahan muatan di dalam kurikulum sekolah. Secara mandiri diwujudkan dalam mata pelajaran tersendiri ataukah melalui integrasi pesan penanaman karakter bangsa disetiap mata pelajaran yang ada (Baron et al., 2018). Sekolah memiliki kultur yang dapat dilihat seperti: arsitektur, tata ruang, eksterior dan interior, dan kebiasaan (Wende, Desri Nora, 2018).

Sekolah sebagai lembaga pendidikan mempunyai kebijakan tertentu yang dituangkan dalam bentuk aturan sekolah yang disebut dengan tata tertib. Siswa dituntut untuk menaati tata tertib sekolah, dengan demikian akan membentuk karakteristik siswa agar disiplin dan bertanggung jawab. (Sylvia, 2012). Salah satu tantangan yang harus dihadapi adalah perbaikan sektor Sumber Daya Manusia (SDM) yang dapat diantisipasi melalui peningkatan kualitas pendidikan. Hal yang paling fundamental adalah mengubah pola pikir dan sifat peserta didik dalam mengembangkan kemampuannya dalam menghadapi revolusi industri 4.0 sehingga dapat menjadi sumber daya manusia yang unggul. (Sylvia et al., 2019).

Oleh karena itu pengembangan kurikulum saat ini masih menggunakan klasifkasi taxonomy belajar dari Benyamin Bloom dan Anderson and Krathwohl secara garis besar dibagi menjadi tiga ranah, yaitu ranah kognitf, ranah afektif dan ranah psikomotoris. Ranah kognitif berkenaan dengan hasil belajar intelektual yang terdiri atas enam aspek yakni: pengetahuan, pemahaman, aplikasi, analisis, dan evaluasi. Ranah afektif berkenaan dengan sikap yang terdiri dari lima aspek yakni: penerimaan, jawaban atau reaksi, penilaian, organisasi, dan internalisasi. Ranah psikomotor berkenaan dengan hasil belajar keterampilan dan kemampuan bertindak. Pada semua mata pelajaran di sekolah menjadikan ke tiga aspek itu sebagai tolak ukur untuk menilai hasil belajar. Materi yang lebih diprioritaskan dan hasil belajar siswa tidak sama dalam setiap mata pelajaran begitupun pada mata pelajaran sosiologi. Pada mata pelajaran yang lebih bersifat teknis, maka materi pelajaran dan hasil belajar lebih banyak menemukan aspek psikomotor. Sedangkan mata pelajaran sosiologi lebih banyak menekankan kepada aspek kognitif. Siswa diharapkan lebih menguasai materi pembelajaran yang banyak bersifat pada konsep sehingga siswa lebih dapat mencapai hasil belajar yang diinginkan. Di sekolah siswa lebih dituntut untuk dapat mencapai hasil belajar yang maksimal. Hasil belajar siswa harus mencapai Kriteria Ketuntasan Minimal (KKM). Besaran nilai KKM sesuai pada sekolah masing-masing. Di SMA Negeri 4 Padang KKM pada mata pelajaran sosiologi yakni 80. Namun, pada kenyataannya masih ada hasil belajar sosiologi siswa yang berada dibawah nilai KKM, khususnya pada kelas XI IPS yang dapat dilihat pada tabel di bawah ini.

Tabel 1. Hasil Belajar Sosiologi Siswa K1s XI IPS SMA Negeri 4 Padang

\begin{tabular}{cc}
\hline Kelas & Nilai MID Semester \\
\hline XI IPS 1 & 45.80 \\
\hline XI IPS 2 & 46.88 \\
\hline XI IPS 3 & 44.84 \\
\hline
\end{tabular}

Sumber: Pengolahan Data Primer 2019

Jurnal Sikola: Jurnal Kajian Pendidikan dan Pembelajaran Vol. 1, No. 3, Th. 2020 
Dapat kita ketahui dari tabel di atas terlihat bahwa hasil belajar mata pelajaran sosiologi siswa kelas XI IPS di SMA Negeri 4 Padang belum mencapai standar nilai yang telah ditetapkan dalam Kriteria Ketuntasan Minimum (KKM). Nilai rata-rata siswa berada pada kisaran 40 sedangkan nilai KKM yang telah ditetapkan oleh sekolah adalah 80 . Siswa yang memilki hasil belajar sosiologi yang berada di bawah nilai KKM kebanyakan berasal dari kelas XI IPS. Dalam pembelajaran berhasil atau tidaknya seseorang dalam belajar disebabkan oleh beberapa faktor yang dapat mempengaruhi pencapaian hasil belajar yaitu yang berasal dari dalam peserta didik (faktor internal) dan ada pula yang berasal dari luar peserta didik (faktor eksternal).

Dari paparan di atas salah satu faktor yang dapat mempengaruhi hasil belajar siswa adalah faktor internal yakni karakter disiplin siswa itu sendiri. Siswa yang berasal dari kelas XI IPS memiliki tingkat kedisiplinan yang rendah. Peneliti juga mendapatkan data dari guru Bimbingan dan Konseling dimana nilai karakter disiplin siswa belum tertanam dengan baik oleh siswa kelas XI IPS yang mana selama proses belajar mengajar pada bulan September saja siwa kelas X IPS yang tidak dating tanpa kabar (absen) sejumlah 84 kali, Izin sebanyak 94 kali, Sakit sebanyak 39 kali, dan cabut sejumlah 13 kali. Dari observasi yang dilaksanakan saat melaksanakan PPL Januari - Juni 2019 di SMA Negeri 4 Padang. Indikasi membuktikan nilai karakter disiplin di SMA Negeri 4 Padang belum tertanam dengan baik. Berdasarkan observsi awal di SMA Negeri 4 Padang kelas XI IPS diperoleh data sebagai berikut: Masih ada siswa yang terlambat masuk sekolah atau masuk kelas setelah jam istirahat

Berdasarkan data tersebut, peneliti dapat menyimpulkan bahwa siswa kelas XI IPS di SMA Negeri 4 Padang nilai karakter belum tertanam dengan baik. Karakter adalah nilai dasar yang membangun pribadi seseorang, terbentuk baik karena pengaruh hereditas maupun pengaruh lingkungan, yang membedakannya dengan orang lain, serta diwujudkan dalam sikap dan perilakunya dalam kehidupan sehari-hari. Nilai karakter yang kurang tertanam dengan baik dapat mempengaruhi siswa dimasa yang akan datang. Karakter dapat dimaknai sebagai nilai dasar yang dapat membangun pribadi pada diri seseorang, terbentuk dengain baik karena pengaruh watak maupun pengaruh lingkungan, yang dapat membedakannya dengan orang lain, serta diwujudkan dalam sikap dan perilaku dalam kehidupan sehari-hari (Muschlas Sumani \& Hariyanto, 2011). Lunturnya nilai-nilai karakter tersebut, hakikatnya merupakan bagian dari karakter individu. Individu yang memiliki karakter baik adalah individu yang bisa membuat keputusan dan siap mempertanggung jawabkan setiap akibat dari perbuatannya. Demikian sebaliknya, individu yang berkarakter jelek jauh dari perbuatan terpuji (Assidiqi, 2015). Karakter merupakan cara berpikir dan berperilaku yang dapat membedakan setiap individu untuk hidup dan bekerjasama (Suradi, 2017). Karakter merupakan ciri khas seseorang yang membedakan kualitas antar individu. Lebih lanjut pernyataan tersebut juga menekankan bahwa karakter tidak hanya apa yang terlihat dipermukaan, melainkan lebih kedalam yakni kepribadian individu tersebut (Apriani \& Wangid, 2015). Karakter juga dapat membentuk cara berpikir dan berperilaku yang menjadi ciri khas tiap individu untuk hidup dan bekerjasama, baik dalam lingkup keluarga, masyarakat, bangsa dan Negara (Wibowo, 2012).

Menurut Lickona terdapat tiga jenis komponen karakter yang penting yaitu pengetahuan moral, perasaan moral, dan penerapan moral. Ketiga komponen tersebut saling mempengaruhi dan membentuk karakter yang baik, oleh sebab itu dalam penanaman nilai karakter harus memperhatikan komponen tersebut. Karakter yang tidak terbentuk secara baik dapat menguasai sikap siswa suatu saat nanti (Nadya Zahratul Atika, 2019). Disiplin merupakan salah satu hal yang paling mendasar pada anak dalam membentukan pribadi anak secara sehat. Disiplin merupakan titik masuk bagi pendidikan karakter bagi sekolah karena jika tidak ada rasa hormat terhadap aturan, otoritas, dan hak orang lain, maka tidak ada lingkungan yang baik bagi pengajaran dan pembelajaran (Nuriyatun, 2016). Tujuan dari disiplin yaitu agar anak dapat mengembangkan pribadinya secara kreatif untuk di kemudian hari (Wara \& Marlina, 2019). Disiplin adalah suatu sikap konsisten dalam melakukan suatu aturan yang menjadi kesepakatan atau menjadi ketentuan (Moh, 2011). Disiplin adalah sikap menghormati, menghargai, patuh

Jurnal Sikola: Jurnal Kajian Pendidikan dan Pembelajaran Vol. 1, No. 3, Th. 2020 
serta taat terhadap peraturan yang berlaku, baik itu berupa peraturan tertulis maupun tidak tertulis serta dapat menjalankannya dan tidak mengingkari untuk menerima sanksi apabila melanggar tugas dan wewenang yang diberikan kepadanya(Bamawaz \& M. Arifin, 2012). Secara umum hasil belajar yaitu kemampuan yang didapati oleh siswa saat melewati pembelajaran, siswa yang lulus saat pembelajaran yaitu berhasil memperoleh tujuan proses belajar mengajar (Mulyono Abdurrahman, 1999). Hasil belajar juga dapat melihat sejauh mana siswa dapat menguasai pembelajaran setelah mengikuti proses belajar mengajar, atau keberhasilan yang dicapai seseorang peserta didik setelah mengikuti kegiatan pembelajaran yang ditandai dalam bentuk angka, huruf, atau symbol tertentu yang telah disepakati oleh pihak penyelenggara pendidikan tersebut (Dimyati dan mudjiono, 2009). Data karakter disiplin dengan hasil belajar siswa tersebut membuat peneliti tertarik untuk meneliti lebih jauh. Tujuan penelitian ini adalah untuk melihat hubungan rendahnya hasil belajar siswa dengan karakter disiplin siswa.

\section{Metode Penelitian}

Pada penelitian ini, pendekatan yang digunakan yaitu pendekatan kuantitatif, penelitian kuantitatif merupakan suatu proses mendapatkan ilmu pengetahuan yang memakai angka sebagai alat analisis keterangan tentang apa yang belum diketahui (Kasiram, 2008) dengan teknik pengumpulan data yaitu angket. Jenis penelitian ini adalah penelitian expost-facto, merupakan penelitian yang dilakukan sesuadah perbedaan dalam variabel bebas yang terjadi karena perkembangan suatu kejadian secara alami (Arif, 2002). Pada penelitian ini terdapat dua variabel yaitu (1) variabel bebas, yaitu variabel yang berpengaruh terhadap variabel lain atau variabel yang menjadi penyebab, (2) variabel terikat yaitu variabel variabel yang dipengaruhi oleh variabel bebas atau variabel yang menerima akibat dari variabel bebas. Teknik pengumpulan sampel yang di pakai adalah proportional random sampling dengan jumlah sampel 78 orang. Dengan menggunakan angket dan dokumentasi.

\section{Hasil dan Pembahasan}

Penelitian karakter disiplin siswa ditetapkan sebagai variabel bebas (indipenden variabel) dan hasil belajar ditetapkan sebagai variabel terikat (dependen variabel). Sampel penelitian berjumlah 78 orang siswa kelas XI IPS SMA Negeri 4 Padang. Setelah sampel ditetapkan, kemudian dilaksanakan pendataan data tentang karakter disiplin siswa dengan 5 indikator yaitu: Ketaatan terhadap tata tertib di sekolah, Ketaatan terhadap kegiatan belajar di sekolah, Ketaatan dalam mengerjakan tugas-tugas pelajaran, mengucap salam, Berdoa ketika beraktifitas. Berdasarkan penilaian, dilakukan uji normalitas dan uji linearitas. Mendapatkan hasil bahwa data berdistrubusi normal dan linear. Pada peneltian ini memakai analisis korelasi Product Moment. Hasil penelitian yang di dapatkan bahwa dari uji korelasi terdapat hubungan karakter disiplin siswa dengan nilai belajar siswa kels XI IPS di SMA Negeri 4 Padang Tahun Ajaran 2019/2020, pada hasil analisis product moment diperoleh nilai $r_{\text {hitung }} 1,402$ dan $r_{\text {tabel }} 0.222$, yang berarti nilai $r_{\text {hitung }}$ lebih besar dari pada nilai $r_{\text {tabel }}$ sehingga dapat dikatakan adanya korelasi antara karakter siswa dengan hasil belajar siswa. Uji korelasi masing-masing indikator menunjukkan semua indikator berkorelasi dengan hasil belajar. Untuk lebih jelasnya dapat dilihat pada tabel berikut:

Tabel 2. Hasil Uji Korelasi Indikator Karakter Disiplin Siswa dengan Hasil Belajar Siswa

\begin{tabular}{llrrl}
\hline No. & \multicolumn{1}{c}{ Indikator } & $\mathbf{r}_{\text {hitung }}$ & $\mathbf{r}_{\text {tabel }}$ & \multicolumn{1}{c}{ Keterangan } \\
\hline 1. & Ketaatan terhadap tata tertib di sekolah & 1,695 & 0,222 & Berkorelasi \\
\hline 2. & Ketaatan terhadap kegiatan belajar di sekolah & 1,185 & 0,222 & Berkorelasi \\
\hline 3. & $\begin{array}{l}\text { Ketaatan dalam mengerjakan tugas-tugas } \\
\text { pelajaran }\end{array}$ & 1,089 & 0,222 & Berkorelasi \\
\hline 4. & Mengucap salam & 0,872 & 0,222 & Berkorelasi \\
\hline 5. & Berdoa ketika beraktifitas & 1,405 & 0,222 & Berkorelasi \\
\hline
\end{tabular}

Sumber: Pengolahan Data Primer, 2019

Jurnal Sikola: Jurnal Kajian Pendidikan dan Pembelajaran Vol. 1, No. 3, Th. 2020 
Dari tabel di atas dapat kita lihat bahwa karakter disiplin siswa semua indikator memberikan kontribusi terhadap hasil belajar siswa. Indikataor karakter disiplin siswa yang lainnya memiliki hubungan dengan hasil belajar karena mamiliki $r_{\text {hitung }}$ lebih besar dari $r_{\text {tabel }}$. Mengenai korelasi masing-masing indikator mengenai karakter disiplin siswa dengan hasil belajar siswa akan diuraikan seperti berikut:

\section{Indikator Ketaatan Terhadap Tata Tertib Di Sekolah}

Indikator pertama yaitu ketaatan terhadap tata tertib di sekolah. Pada indikator ini terdapat hubungan dengan hasil belajar siswa, dimana indikator ini memiliki $r_{\text {hitung }} 1,695$ dan $r_{\text {tabel }} 0,222$ yang berarti indikator ketaatan terhadap tata tertib di sekolah memiliki hubungan dengan hasil belajar siswa. Artinya indikator tersebut memiliki pengaruh terhadap hasil belajar siswa. Menurut (Anggraini \& Subadi, 2016) bentuk ketaatan siswa terhadap tata tertib sekolah dapat berupa pelaksanaan ekstrakurikuler dengan maksud agar siswa tersebut dapat lebih mandiri dan memiliki jiwa pemimpin yang kuat. Siswa yang melanggar tata tertib sekolah tidak akan dikenakan sanksi, akan tetapi berupa pembinaan bagi siswa tersebut agar lebih patuh terhadap peraturan sekolah. Dengan menjalankan tata tertib sekolah dalam pelaksanaan ekstrakurikuler hal tersebut dapat memberikan dampak positif kepada siswa yaitu dapat melatih jiwa kepemimpinan siswa itu sendiri. Menurut Lickona moral knowing adalah hal yang penting untuk diajarkan, dimana sekolah harus menyediakan lingkungan sekolah yang menyediakan nilai-nilai yang baik dan menyimpannya di hadapan hati nurani setiap siswa. dengan kata lain. Disini jelas terlihat jika sekolah mengajarkan siswa untuk membentuk sikap yang baik, dengan ketaatan siswa terhadap tata tertib sekolah dalam bentuk pelaksaan ekstrakurikuler dapat membentuk jati diri siswa secara baik dan dapat berguna bagi siswa untuk dikemudian hari.

\section{Indikator Ketaatan Terhadap Kegiatan Belajar di Sekolah}

Indikator kedua yaitu ketaatan terhadap kegiatan belajar di sekolah. Berdasarkan nilai $\mathrm{r}_{\text {hitung }}$ 1,185 dan $\mathrm{r}_{\text {tabel }}$ 0,222 dimana dari nilai tersebut jelas terlihat bahwa indikator ketaatan terhadap hasil belajar di sekolah memiliki hubungan dengan hasil belajar siswa atau dengan kata lain memberikan pengaruh terhadap hasil belajar. Menurut penelitian (Umi Chulsum, 2015) bahwa sikap disiplin siswa dalam hal ketaatan terhadap kegiatan belajar di sekolah tinggi. Apabila di lingkungan keluarga mampu menciptakan suasana belajar yang nyaman, maka akan mempengaruhi kedisiplinan siswa dalam hal belajar di rumah sehingga siswa dengan mudah siswa mendapatkan hasil belajar yang baik juga. Menurut Lickona dalam teori karakter moral knowing (penalaran moral), hal yang penting diajarkan kepada siswa yaitu terdiri dari penalaran moral. Penalaran moral bukan berarti sekedar suatu tindakan, sehingga kita dapat menilai apakah tindakan itu baik atau buruk tetapi merupakan alasan dari suatu tindakan yang kita lakukan. Disini jelas terlihat bahwa siswa tersebut dapat memposisikan dirinya sendiri ke dalam kondisi apapun, baik itu dalam kondisi buruk seharusnya siswa dapat menilai apakah kondisi tersebut harus tetap diikuti atau berpaling dari kondisi tersebut. Karena siswa sendiri mampu membedakan yang baik dan yang buruk bagi dirinya sendiri.

\section{Indikator Ketaatan dalam Mengerjakan Tugas-Tugas Pelajaran}

Indikator ketiga yaitu ketaatan dalam mengerjakan tugas-tugas pelajaran memiliki nilai $\mathrm{r}_{\text {tabel }}$ 1,089 dan $r_{\text {hitung }} 0,222$ yang mana indikator ini memiliki hubungan dengan hasil belajar siswa atau dapat dikatakan juga mempunyai pengaruh terhadap hasil belajar. Penelitian (Andi Widiatmoko \& Nanik Suryani, 2013) menyebutkan bahwa disiplin belajar siswa terutama dalam hal ketaatan dalam mengerjakan tugas memiliki nilai yang sangat tinggi, siswa yang taat dalam mengerjakan tugas pelajaran maka prestasi belajarnya juga akan meningkat. Lickona menjelaskan ada dalam moral action, ada 3 aspek lain dari karakter yang mendorong siswa dalam peruatan yang baik, salah satu aspek tersebut adalah keinginan (will). Siswa yang

Jurnal Sikola: Jurnal Kajian Pendidikan dan Pembelajaran Vol. 1, No. 3, Th. 2020 
memiliki keinginan yang tinggi untuk mampu mengerjakan tugas pelajaran secara serius pasti dapat mengerjakannya sendiri tanpa perlu bantuan dari teman, karna secara langsung siswa tersebut dapat mengukur tingkat kemampuannya sendiri.

\section{Indikator Mengucapkan Salam}

Indikator keempat yaitu mengucapkan salam. Indikator ini mempunyai nilai $\mathrm{r}_{\text {tabel }} 0,872$ dengan $r_{\text {hitung }}$ 0,222. Dari nilai rtabel dan rhitung tersebut jelas terlihat bahwa indikator mengucapkan salam memiliki hubungan dengan hasil belajar atau dengan kata lain memiliki korelasi. Menurut (Wulandari \& Kristiawan, 2017) siswa sudah sangat terbiasa mengucapkan salam kepada sesama siswa dan kepada karyawan sekolah apabila baru bertemu pada pagi/siang hari dan apabila akan berpisah pada siang/sore hari, dengan begitu siswa secara langsung telah menanamkan nilai karakter religius di dalam diri masing-masing siswa yang pastinya akan terus dibawa dan berguna untuk dikemudian hari. Dalam teori karakter yang dikemukakan oleh Lickona yaitu dinamakan dengan moral action artinya bagaimana membuat pengetahuan moral dapat diwujudkan menjadi tindakan nyata. Jelas terlihat bahwa nilai yang tertanamkan pada diri siswa terus diajarkan dalam setiap kesempatan sehingga menjadi kebiasaan yang sangat positif bagi siswa untuk dikemudian harinya.

\section{Indikator Berdoa Sebelum Belajar}

Indikator keempat yaitu berdoa sebelum belajar. Pada indikator ini nilai $\mathrm{r}_{\text {hitung }}$ lebih besar dibandingkan nilai $r_{\text {tabel }}$. Dimana nilai $r_{\text {hitung }} 1,405$ dan $r_{\text {tabel }}$ 0,222 dan juga berarti memiliki hubungan dengan hasil belajar siswa. Dalam penelitian (Hariandi, 2016) menyebutkan bahwa sikap religius di dalam diri siswa secara sadar tertanam dengan sangat baik. Terbukti dengan sikap berdoa sebelum dan sesudah belajar selalu dilakukan oleh siswa, serta guru pun juga terus menjalankan kegiatan ini karena dalam proses pembelajaran pun sudah termasuk ke dalam bagian indikator pembelajaran. Menurut teori karakter Lickona, dalam pengetahuan moral hal yang paling penting untuk diajarkan kepada siswa dapat berupa moral knowing values (mengetahui nilai-nilai moral). Mengetahui sebuah nilai juga berarti memahami bagaimana caranya menerapkan nilai yang bersangkutan dalam berbagai situasi (Lickona, 2016). Disini, guru mengajarkan kepada siswa untuk berdoa sebelum proses belajar dimulai, guru memberikan contoh kepada siswa sehingga siswa terus menjalankan nilai yang diajarkan oleh guru tersebut. Pengembangan karakter yang harus seimbang dengan nilai agama dan budaya masyarakat.(Dendy Marta Putra, n.d.)

Hasil penelitian sesuai dengan pendapat teori karakter dari Lickona yang menyatakan bahwa karakter berkaitan dengan konsep moral, sikap moral dan perilaku moral, karakter yang dibelajarkan dengan baik pada proses pembelajaran akan memperlihatkan munculnya pengetahuan tentang kebaikan, keinginan untuk berbuat baik dan melakukan perbuatan baik, sehingga hasil belajar sebagai output dari proses pembelajaran akan berhasil baik..

\section{Kesimpulan}

Hubungan Karakter Disiplin dengan Hasil Belajar Siswa Kelas XI IPS SMA Negeri 4 Padang (1) Berdasarkan hasil analisis, penelitian ini menunjukkan adanya hubungan positif antara Karakter Disiplin dengan Hasil Belajar Siswa di SMA Negeri 4 Padang. Melalui analisis korelasi Product Moment diperoleh $\mathrm{r}_{\text {hitung }}$ lebih besar dari $\mathrm{r}_{\text {tabel }}$ dengan nilai $\mathrm{r}_{\text {hitung }}=2,216>\mathrm{r}_{\text {tabel }}=$ 0,222 dengan $\mathrm{N}=78$ pada taraf signifikansi $5 \%$. Hal ini berarti terdapat hubungan positif dan signifikan antara Karakter Disiplin dengan Hasil Belajar Siswa SMA Negeri 4 Padang. Dengan demikian dapat dikatakan bahwa semakin tinggi Karakter Disiplin, maka akan semakin tinggi Hasil Belajar Siswa. (2) Pada karakter disiplin, terdapat 5 indikator yang secara keseluruhan memiliki korelasi dengan hasil belajar Pertama, indikator ketaatan terhadap tata tertib di sekolah memiliki $r_{\text {hitung }} 1,007$ dengan $r_{\text {tabel }}$ 0,222. Kedua, indikator ketaatan terhadap kegiatan belajar di 
sekolah, pada indikator ini nilai $r_{\text {hitung }} 1.185$ dan nilai $r_{\text {tabel }} 0,222$. Ketiga, indikator ketaatan dalam mengerjakan tugas-tugas pelajaran, memiliki nilai $r_{\text {tabel }} 1,089$ dan $r_{\text {hitung }} 0,222$. Keempat, indikator mengucapkan salam. Memiliki nilai $r_{\text {hitung }} 0,872$ dan $r_{\text {tabel }} 0,222$. Kelima, indikator berdoa ketika berktivitas. Nilai $r_{\text {hitung }} 1,405$ dengan $r_{\text {tabel }}$ 0,222. (3) Kelima indikator tersebut memiliki korelasi terhadap hasil belajar karena nilai $r$ hitung lebih tinggi dibandingkan nilai $r$ tabel, karena itulah indikator tersebut mempunyai hubungan terhadap hasil belajar. (3) Penanaman nilai baik akan menghasilkan perilaku baik jika dimulai dengan pemberian pengetahuan, pembiasaan sikap baik sehingga menghasilkan perilaku yang baik.

\section{Daftar Pustaka}

Andi Widiatmoko \& Nanik Suryani. (2013). Pengaruh Motivasi Belajar Dan Disiplin Terhadap Prestasi Belajar Pada Mata Diklat Mengelola Peralatan Kantor Kelas X Jurusan Administrasi Perkantoran Smk Teuku Umar Semarang Tahun Pelajaran 2013/2014. 2(1), 18-23.

Anggraini, E. N., \& Subadi, T. (2016). Pengelolaan Tata Tertib Sekolah Menengah Pertama. Jurnal VARIDIKA, 27(2), 144-151. https://doi.org/10.23917/varidika.v27i2.1726

Apriani, A., \& Wangid, M. N. (2015). Pengaruh Ssp Tematik-Integratif Terhadap Karakter Disiplin Dan Tanggung Jawab Siswa Kelas Iii Sd. Jurnal Prima Edukasi, 3(1), 12-25. https://doi.org/10.21831/jpe.v3i1.4061

Arif, F. (2002). Pengantar Penelitian Dalam Pendidikan. Yogyakarta: Pustaka Pelajar.

Assidiqi, H. (2015). Membentuk karakter peserta didik melalui model pembelajaran search, solve, create, and share. Math Didactic: Jurnal Pendidikan Matematika, 1(1), 45-55. https://doi.org/10.33654/math.v1i1.94

Atika, S. (2014). Pelaksanaan Pendidikan Karakter (Religius, Cinta Tanah Air Dan Disiplin) Di SLB Al Ishlaah Padang. E-JUPEKhu, 3(3), 747-755.

Bamawaz \& M. Arifin. (2012). Strategi dan Kebijakan Pembelajaran Pendidikan Karakter. Yogyakarta: Ar-Ruzz Media.

Baron, A., Bedore, L. M., Peña, E. D., Lovgren-Uribe, S. D., López, A. A., \& Villagran, E. (2018). Research article. American Journal of Speech-Language Pathology, 27(3), 975-987. https://doi.org/10.1044/2018_AJSLP-17-0074

Baroroh, K. (2012). Upaya Meningkatkan Nilai-Nilai Karakter Peserta Didik Melalui Penerapan Metode Role Playing. Jurnal Ekonomi Dan Pendidikan, 8(2), 149-163. https://doi.org/10.21831/jep.v8i2.793

Dendy Marta Putra, N. N. (n.d.). Lesson Study dalam Meningkatkan Ketrampilan 4C (Critical Thingking, Collaborative, Communicative dan Creative) pada Pembelajaran Sosiologi yang Terintegrasi ABS-SBK di SMAN 1 Pasaman. Retrieved from http://sikola.ppj.unp.ac.id/index.php/sikola/article/view/19

Dimyati dan mudjiono. (2009). Belajar dan Pembelajaran. Jakarta: rineka cipta.

Hariandi, D. (2016). Peran Guru dalam Penanaman Nilai Karakter Religius di Lingkungan Pada Siswa Sekolah Dasar. 1(20), 176-189.

Kasiram, M. (2008). Metode Penelitian Kuantitatif. Malang: UIN Malang Press.

Lickona, T. (2016). Mendidik Untuk Membentuk Karakter: Bagaimana Sekolah Dapat Mengajarkan Sikap Hormat dan Tanggung Jawab. Jakarta: PT. Bumi Aksara.

Moh, S. (2011). Pendidikan Karakter di Sekolah. Surabaya: Jaring Pena.

Mulyono Abdurrahman. (1999). Pendidikan Bagi Anak Berkesulitan Belajar (Jakarta). Rineka Cipta. Muschlas Sumani \& Hariyanto. (2011). Konsep dan Model Pendidikan Karakter. Bandung: PT. Reamaja Rosdakarya.

Nadya Zahratul Atika, J. J. (2019). Hubungan Karakter Siswa dengan Hasil Belajar Sosiologi Siswa Kelas X dan XI IPS di SMA Negeri 2 Batang Anai Kabupaten Padang Pariaman. Sikola, 1(1), 20-27. https://doi.org/https://doi.org/10.24036/sikola.v1i1.4

Nuriyatun, P. D. (2016). Implementasi Pendidikan Karakter Disiplin Dan Tanggung Jawab Di

Jurnal Sikola: Jurnal Kajian Pendidikan dan Pembelajaran Vol. 1, No. 3, Th. 2020 
Sd Negeri 1 Bantul. Basic Education, 5(33), 3-174.

Rosniati Haim. (2014). Pembentukan Karakter Peserta Didik Melalui Pendidikan Berbasis A1Quran. Jurnal Pendidikan Karakter, (2), 123-136. https://doi.org/10.21831/jpk.v0i2.2788

Suradi, S. (2017). Pembentukan Karakter Siswa melalui Penerapan Disiplin Tata Tertib Sekolah. Briliant: Jurnal Riset Dan Konseptual, 2(4), 522. https://doi.org/10.28926/briliant.v2i4.104

Sylvia, I. (2012). Hubungan Antara Konformitas Kelompok Teman Sebaya dengan Disiplin Siswa SMAN 5 Padang. Diakronika, Vol XII, No 1 Th 2012, XII(1), 205-213. https://doi.org/10.31227/osf.io/tm5ba

Sylvia, I., Anwar, S., Khairani, K., Padang, U. N., Autentik, P., \& Sosiologi, P. (2019). Pengembangan Instrumen Penilaian Autentik Berbasis Pendekatan Authentic Inquiry Learning pada Mata Pelajaran Sosiologi di Sekolah Menengah Atas. 6(2), 103-120. https://doi.org/http://socius.ppj.unp.ac.id/index.php/socius/article/view/162

Umi Chulsum. (2015). Pengaruh Lingkungan Keluarga, Kedisiplinan Siswa, dan Motivasi Belajar Terhadap Hasil Belajar Ekonomi Siswa di SMA Negeri 7 Surabaya. Surabaya.

Wara, Z. A., \& Marlina, S. (2019). Jadwal Kegiatan pada Sekolah Sehari Penuh dalam Menanamkan Kedisiplinan. Jurnal PG-PAUD Trunojoyo: Jurnal Pendidikan Dan Pembelajaran Anak Usia Dini, 6(1), 56. https://doi.org/10.21107/jpgpaud.v6i1.5376

Wende, Desri Nora, E. (2018). Strategi Adaptasi Mahasiswa UNP Non Muslim Dalam Kegiatan Praktek Kependidikan (PLK) Pada Sekolah Praktek Lapangan Di Kota Padang. 1(4), 11-16.

Wibowo, A. (2012). Pendidikan Karakter: Strategi Membangun Karakter Bangsa Berperadaban. Yogyakarta: Pustaka Belajar.

Wulandari, Y., \& Kristiawan, M. (2017). Strategi Sekolah Dalam Penguatan Pendidikan Karakter Bagi Siswa Dengan Memaksimalkan Peran Orang Tua. JMKSP (Jurnal Manajemen, Kepemimpinan, Dan Supervisi Pendidikan), 2(2), 290-302. 